\title{
Study of a Photovoltaic System as an Emergency Power Supply for Offshore Plant Facilities
}

\author{
Gun Hwan Choi $\circledast^{* * * *}$, Byung Ho Lee*, Rho-Taek Jung ${ }^{* * * *}$ and Kyubo Shin ${ }^{* * * *}$ \\ "Department of Civil and Environmental Engineering, Ulsan University, Ulsan, Korea \\ "School of Mechanical, Aerospace and Nuclear Engineering, UNIST, Ulsan, Korea \\ ${ }^{*}$ Department of Naval Architecture and Ocean Engineering, Ulsan University, Ulsan, Korea \\ School of Electrical and Computer Engineering, UNIST, Ulsan, Korea
}

\author{
최군환(10*** 이병호* 정노택 ${ }^{* * *}$ - 신규보 ${ }^{* * * *}$ \\ "울산대학교 건설환경공학부 \\ *울산과학기술원 기계항공 및 원자력공학부 \\ 울산대학교 조선해양공학부 \\ 울산과학기술원 전기전자컴퓨터공학부
}

해양플랜트 설비의 비상전원공급을 위한 태양광 발전시스템 연구

KEY WORDS: Renewable portfolio standard 신재생에너지 의무할당제, Photovoltaic effect 광기전력 효과, Solar cell 태양전지, Offshore plant 해양플랜트, Conversion efficiency 변환효율, Wind pressure 풍압력

\begin{abstract}
The use of eco-friendly energy in the offshore plant system is expanding because conventional generators are operated by fossil fuel or natural gas. Eco-friendly energy, which replaces existing power generation methods, should be capable of generating the power for lighting protection equipment, airborne fault indication, parameter measurement, and others. Most of the eco-friendly energy used in offshore plant facilities is solar and wind power. In the case of using photovoltaic power, because the structure must be constructed based as flat solar panels, it can be damaged easily by the wind. Therefore, there is a need for a new generation system composed of a spherical structure that does not require a separate structure and is less influenced by the wind. Considering these characteristics, in this study we designed, fabricated, and tested a unit that could provide the most efficient spherical photovoltaic power generation considering wind direction and wind pressure. Our test results indicated that the proposed system reduced costs because it did not require any separate structure, used eco-friendly eneroy, reduced carbon dioxide emissions, and expanded the proportion of eco-friendly energy use by offshore plant facilities.
\end{abstract}

\section{1. 서 론}

1997년 일본 교토에서 개최된 기후변화협약 당사국총회에서 지구 온난화 규제 및 방지를 위한 국제협약인 기후변화협약의 구체적인 이행 방안으로 선진국의 온실가스 감축 목표치를 규 정하였으며, 2005년 2월 공식적으로 발효되었다. 한국은 기후변 화 협약 개발도상국으로 분류되어 의무 이행 대상국에서 제외 되었으나, 몇몇 선진국에 의해 멕시코 등과 같이 2008년부터 온 실가스 감축의 자발적인 의무부담을 요구받았으며, 정부는 2015 년부터 탄소 배출권 거래제를 시행하여 저탄소 기술 개발 촉진, 저탄소 산업 육성에 노력을 기울이고 있다(Shin, 2015).
해양플랜트 설비는 대부분 화석연료를 사용하는 발전기를 통 해 전력을 수급하고 있다. 이는 해양대기오염의 요인으로 작용 하고 있으며 이러한 설비의 고장 시 기본적으로 비상용 발전기 및 축전용 배터리 등의 가동으로 기간을 보전하고 있는 실정이 다. 비상시 계속 사용할 수 있는 발전시스템의 구성이 필요하여 태양광 전지를 사용하고 있는 경우도 있으나 그 형태가 해양플 랜트에 설치하기엔 부적합한 것이 사실이다. 현재 사용되고 있 는 고정식 평판 태양광 발전 설비는 외형의 특징상 바람의 영 향을 크게 받기 때문에 대형의 구조물을 필요로 하는데 이러한 구조물은 안전성이나 하중이 문제가 되기 때문이다. 또한 해수 의 염분에 의한 성능저하로 인해 유지보수가 용이해야하지만

Received 25 April 2018, revised 10 August 2018, accepted 13 August 2018

Corresponding author Gun Hwan Choi: +82-52-217-2303, kingsunchoi@unist.ac.kr ORCID: https://orcid.org/0000-0003-2845-180X

(c) 2018, The Korean Society of Ocean Engineers

This is an open access article distributed under the terms of the creative commons attribution non-commercial license (http://creativecommons.org/licenses/by-nc/3.0) which permits unrestricted non-commercial use, distribution, and reproduction in any medium, provided the original work is properly cited. 
기존의 발전시스템은 이 점에서 단점이 있다.

본 논문에서는 이러한 문제점들을 해결하기 위해 해양플랜트 환경에 적합한 보(Beam)를 이용한 구조물과 구형의 태양광 발 전단구를 제안한다. 제안된 방식은 고정식 평판 태양광 발전 방 식에 비해 가볍고 작아 기존 대형 구조물의 단점이었던 안전성 이나 하중으로 인한 문제가 없고 유지보수도 간단한 것이 특징 이다. 또한 본 연구에서 설계한 구 형태의 발전단구는 얇은 보 만 있으면 설치할 수 있다. 실제 발전량 실험을 통해 제안 방식 이 고정식 평판 태양광 발전 방식에 비해 발전량은 작은 것으 로 나타났지만 설치비용까지 고려했을 때 더욱 경제적임을 알 수 있었다.

본 논문의 내용은 다음과 같다. 2장에서는 관련 연구 및 기존 해양플랜트 태양광 발전시스템의 문제점을 다루고 3장에서는 이를 해결하기 위한 새로운 태양광 발전시스템을 제안한다. 4장 에서는 풍하중을 고려했을 때 제안된 발전단구와 기존 태양광 패널의 적합성을 평가하며 5 장에서는 각 패널의 전력을 비교하 고 6장에서는 각 방식의 경제성을 비교한다. 7 장에서는 본 논문 의 결론을 내린다.

\section{2. 관련 연구 문헌 조사 및 기존 발전시스템의 문제점}

\section{1 조선 · 해양 분야에서의 태양광 발전}

주로 육상에서 이용되던 태양광 발전 방식이 점차 해상에서도 이용되고 있다. 가장 먼저 선박의 동력의 일부를 태양광 발전으 로 충당하는 연구들이 이루어졌었다(Lee et al., 2017a; Oh et al., 2016). 이는 모든 산업분야에서 공통적으로 이루어지고 있는 온 실가스 감축의 일환으로 볼 수 있지만 일반적인 선박 운용에 필 요한 총 전력량을 충당하지는 못하는 것으로 나타났다.

해양플랜트에서는 선박에서와 달리 비상전원공급을 위한 보 조전력을 확보하는 수단으로 $\mathrm{CO}_{2}$ 를 포함한 온실가스를 발생시 키는 기존의 디젤 발전기 대신 태양광 발전을 포함한 친환경 에 너지를 활용하는 방안이 국내외에서 연구 중이다. Sanchez and Oliveira(2015)에서는 비상전원공급을 위한 디젤 발전기를 포함 하여 해양플랜트에서의 $\mathrm{CO}_{2}$ 배출에 대해 연구하였고 Abdullah et al.(2018)에서는 ESS(Energy storage system)에 태양광 발전이나 풍력 발전으로 전력을 충전시켜 디젤 발전기와 함께 쓰는 방안
을 제시하였다.

선박이나 해양플랜트에서의 태양광 발전이 해당 장소에서 필 요한 전력을 공급하기 위한 방식으로 쓰였다면 최근에는 바다 위의 태양광 발전소로써 부유식 태양광 발전 플랜트가 연구, 적 용되고 있다(Sahu et al., 2016). 하지만 아직 국내에는 연안에서 의 태양광 발전시설만이 있을 뿐 해상에서의 발전시설은 없는 상태이다(Lee et al., 2015).

\section{2 풍하중을 고려한 태양광 발전시스템}

기존의 태양광 발전 패널은 주로 주택 옥상이나(Jeon and Kim, 2010; Kang, 2016) 저수지(Choi et al., 2010; Lee et al., 2017b) 등의 수면 위에 설치되었기 때문에 평판 패널의 외형적 특성으로 발생하는 풍하중에 대한 취약성에 대해 고려하지 않 은 채 모든 셀에서의 일조량을 극대화하여 발전량을 높이기 위 해 평판형으로만 설계되었었다. 하지만 바다 위의 해양플랜트 환경에서는 풍하중을 견디기 위해 구조물이 대형화되어야 하는 점이 해양플랜트 자체에 엄청난 무리를 가할 뿐만 아니라 유지 보수에도 문제가 되고 비상전원공급을 위한 발전시스템이라는 점에서 발전량의 손해는 일정 부분 감수할 수 있기 때문에 어 떠한 환경에서보다도 태양광 발전 모듈 및 시스템 설계에 있어 구조물의 중량 및 풍하중의 영향이 크다고 볼 수 있다.

하지만 해양플랜트에 설치하는 방안을 포함하여 모든 적용 분야를 통틀어 태양광 발전시스템에서 풍하중을 고려한 연구들 은 Ha et al.(2012), Kim et al.(2013), Kim et al.(2017)에서와 같이 평판형 태양광 발전시스템에 작용하는 풍하중에만 집중하였고 이를 완화하기 위해 발전 모듈이나 구조물의 형상을 변화시키 는 연구는 국내외에 없었던 것으로 조사되었다.

따라서 본 연구의 핵심 목표인 해양플랜트 위에 설치할 수 있 는 태양광 발전 시스템을 구성하는 구조물의 중량을 줄이면서 해당 구조물에 적합한 태양광 발전 패널을 설계하고 해양플랜 트 설비의 비상전원공급을 담당할 수 있음을 보이는 것은 국내 외를 통틀어 새로운 시도라고 할 수 있다.

\section{3 기존 해양플랜트 태양광 발전시스템의 문제점}

기존 해양플랜트 설비의 비상전원공급을 위한 태양광 발전설 비는 Fig. 1(a)와 같이 고정식 평판 태양광 발전 패널을 부착하

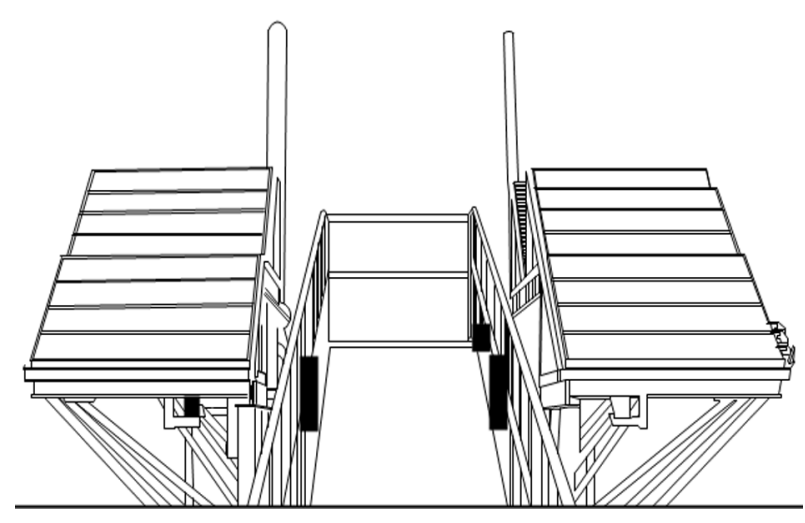

(a) Existing photovoltaic system

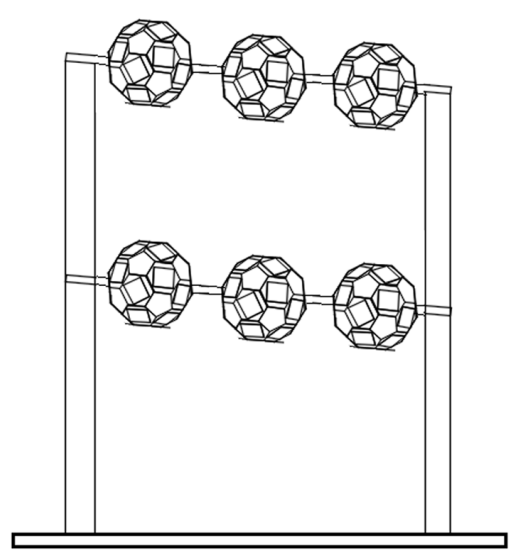

(b) Proposed photovoltaic system

Fig. 1 Photovoltaic systems for offshore plants 
고 있으며 패널에 작용하는 풍하중을 버티기 위해 대형 구조물 이 있는 형태이다. 이런 구조물은 보통 수 톤의 중량을 가지기 때문에 해양플랜트 설비에 무리를 주며 가격도 높다. 또한 발전 패널에 계속적으로 작용하는 풍하중으로 인해 결국 안전성에 문제가 되는 경우가 많고, 해수의 염분이 쌓이기 쉬운 평판형 구조이기 때문에 성능저하를 막기 위해 유지보수가 쉬워야 하 지만 그렇지 않은 단점이 있다. 개별 패널 또는 개별 모듈의 고 장이 있을 시 해당 부분만 교체가 쉽지 않은 것도 해양플랜트 환경에서의 문제점 중 하나로 지적된다.

\section{3. 보를 이용한 구조물과 구형 태양광 발전단구를 이용한 태양광 발전시스템}

\section{1 보를 이용한 구조물}

본 논문에서는 2.3절에서 언급한 기존 고정식 평판 태양광 발전 시스템에서 필연적으로 설치할 수밖에 없었던 대형 구조물의 문 제점을 해결하기 위해 Fig. 1(b)와 같은 형태의 보를 이용한 구조 물을 제안한다. 해당 구조물은 기존의 구조물에 비해 경량인 점으 로 인해 해양플랜트 설비에 큰 부담을 주지 않으면서 저렴한 것이 특징이다. 또한 복잡하지 않은 구조 덕분에 구조물 자체의 유지보 수가 용이하며 문제가 있는 패널의 교체도 쉬운 장점이 있다.

하지만 이러한 구조물에서는 보가 견딜 수 있는 힘이 매우 제 한적이기 때문에 설치할 태양광 발전 패널이 보에 작용하는 힘 을 고려해야 한다. 해양플랜트 환경에서 가장 중요한 힘은 풍하 중인데 기존의 평판 태양광 발전 패널은 그 형태로 인해 바람 이 평판에 수직으로 작용할 때의 풍하중까지 고려할 수밖에 없 고 그 값은 매우 크다. 따라서 본 연구에서는 구형의 발전단구 3 가지를 설계하여 각 발전단구 별로 풍하중과 발전량을 기존의 평판식 발전 패널과 비교하였다.

\section{2 구형 태양광 발전단구}

본 연구에서는 3.1 절에서 언급한 것과 같이 기존의 평판식 발 전 패널(Type A)과 함께 3 가지 구형 발전단구(Type B, C, D)를 고려하였고 각각의 특징은 Table 1 과 같다. 마지막 행의 셀들의 연결 방식을 살펴보면 Type $\mathrm{A}, \mathrm{B}, \mathrm{D}$ 의 경우 인접한 셀들을 먼 저 직렬로 연결한 후 병렬로 연결하였다. 예를 들어, Type $\mathrm{D}$ 의 경우 총 144 개의 셀들을 6 개씩 직렬로 연결한 다음 그렇게 연 결된 24개의 묶음을 병렬로 연결한 것이 된다. Type C의 경우는 모든 셀들이 병렬로 연결되어 있다.

\section{4. 풍하중 고려 시 태양광 발전단구의 적합성 평가}

본 장에서는 Table 1 과 같이 설계된 각 패널 별로 최대 풍하 중(Type $\mathrm{A}$ 의 경우 바람이 평판의 수직 방향으로 불 때)을 계산 하여 Fig. 1(b)와 같은 구조물에 설치 가능 여부를 평가한다.

각 패널은 Fig. 2와 같이(Type A는 Fig. 2(a)와 같이, Type B, $\mathrm{C}, \mathrm{D}$ 는 Fig. 2(b)와 같이) 단면이 정사각형인 보에 등간격, 좌우 대칭으로 설치되어 있다고 설정하였다. 이와 같은 설치 형태에 서는 작용하는 힘도 좌우 대칭이므로 Fig. 3에서와 같이 대칭면 을 기준으로 한 편만 고려해도 되고, 이 때 최대의 휨 모멘트가 작용하는 접합부(Fig. 3의 A 지접)에서 각 패널에 작용하는 풍 하중으로 인해 발생하는 응력을 계산하였다. 풍하중을 계산하 기 위한 식은 식 (1)과 같다(Fox et al., 2010).
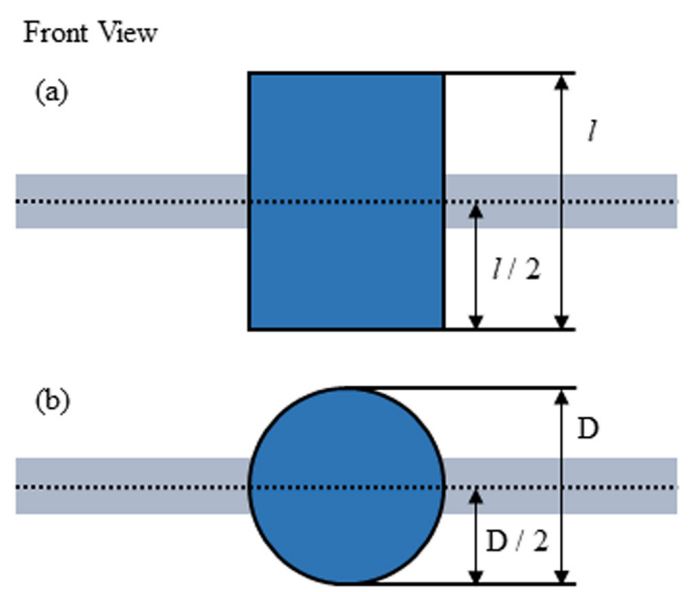

Fig. 2 Photovoltaic panel attachment to the beam

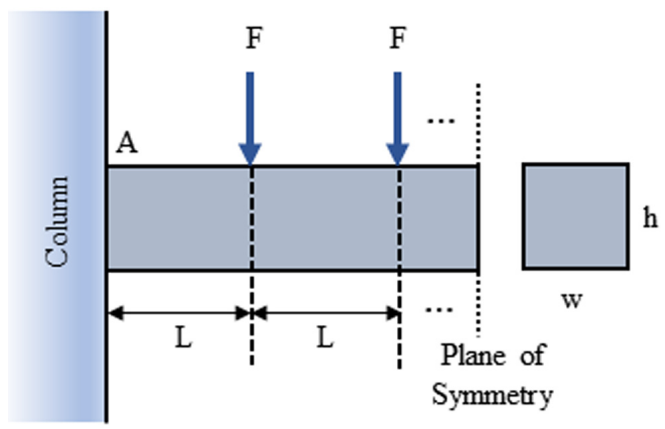

Fig. 3 Stress at the point A

Table 1 Four different types of photovoltaic panels

\begin{tabular}{ccccc}
\hline \hline & Type A & Type B & Type C & Type D \\
\hline Shape & Rectangle & 32-sided shape & Pentagonal shape & Sphericity \\
Size & $527 \mathrm{~mm} \times 1,037 \mathrm{~mm}$ & Diameter : $650 \mathrm{~mm}$ & Diameter : $600 \mathrm{~mm}$ & Diameter : $540 \mathrm{~mm}$ \\
Weight $[\mathrm{kg}]$ & 4.85 & 3.35 & 3.80 & 3.60 \\
Power [W] & 50 & 69 & 41.4 & 25.9 \\
Voltage [V] & 20 & 20 & 20 & 20 \\
Number of cells & 33 & 30 & 10 & 144 \\
(Connection between cells) & (Series: 3 & (Series: 3 & (Parallel: 10) & (Series: 6 \\
\hline
\end{tabular}


Table 2 Variables used for eq. (1)

\begin{tabular}{cc}
\hline \hline Density of air, $\rho$ & $1.2041 \mathrm{~kg} / \mathrm{m}^{3}\left(20{ }^{\circ} \mathrm{C}\right)$ \\
\hline Wind speed, $V$ & $60 \mathrm{~m} / \mathrm{s}$ (MAEMI, 2003) \\
\hline Drag coefficient, $C_{D}$ & 2.05 (Type A)- Square prism \\
& 0.38 (Type B, C, D)- Hemisphere \\
\hline & $0.546 \mathrm{~m}^{2}$ (Type A) \\
$0.332 \mathrm{~m}^{2}$ (Type B) \\
Cross-sectional Area, $A$ & $0.283 \mathrm{~m}^{2}$ (Type C) \\
& $0.229 \mathrm{~m}^{2}$ (Type D) \\
\hline
\end{tabular}

$$
F=\frac{1}{2} \rho V^{2} A C_{D}
$$

이 때, 각 변수들의 정의와 해당하는 값은 Table 2 와 같다(Fox et al., 2010). 식 (1)로 계산한 풍하중은 다음과 같다.

$$
\begin{aligned}
F_{A} & =2.43 \mathrm{kN} \\
F_{B} & =0.55 \mathrm{kN} \\
F_{C} & =0.47 \mathrm{kN} \\
F_{D} & =0.38 \mathrm{kN}
\end{aligned}
$$

위의 값은 각각 패널의 자중 $(32.8 \mathrm{~N} \sim 47.5 \mathrm{~N})$ 에 비해 훨씬 큰 값이기 때문에 이후의 계산에서는 자중을 제외한 풍하중만 고 려하였다. 풍하중에 의한 보의 최대 인장 응력은 식 (2)를 이용 하여 구할 수 있다(Beer et al., 2009).

$$
\begin{aligned}
\sigma & =\frac{M c}{I}=\frac{\sum(\vec{F} \times \vec{d}) c}{I} \\
& =\left(\frac{1}{2} \rho V^{2} A C_{D}\right)\left[\frac{3 L(N+1)^{2}}{4 w h^{2}}\right]
\end{aligned}
$$

패널의 개수 $N$ 은 9 , 수평경간은 $8 \mathrm{~m}$, 패널 사이의 거리 $L$ 은 $800 \mathrm{~mm}$, 보의 두께는 가로 $(w)$, 세로 $(h) 50 \mathrm{~mm}$ 로 설정하였고 보 의 재질은 구조용 강으로 일반적으로 쓰이는 ASTM A36으로 가정하였으며 해당 물질의 허용 응력 $\sigma_{\text {allow }}$ 는 $250 \mathrm{MPa}$ 이다(Beer et al., 2009).

각 형상별 패널에 의한 응력은 다음과 같이 계산된다.

$$
\begin{aligned}
\sigma_{A} & =1.17 \mathrm{GPa} \\
\sigma_{B} & =131.18 \mathrm{MPa} \\
\sigma_{C} & =111.78 \mathrm{MPa} \\
\sigma_{D} & =90.54 \mathrm{MPa}
\end{aligned}
$$

각 패널 별 $\sigma$ 와 $\sigma_{\text {allow }}$ 를 비교함으로써 해당 패널이 보에 설치 되어도 보가 버틸 수 있는지 알 수 있는데 Type $\mathrm{B}, \mathrm{C}, \mathrm{D}$ 는 허용 응력까지 최대 약 두 배까지의 여유가 있지만 Type $\mathrm{A}$ 는 허용 응력을 4배 이상 초과하기 때문에 설치가 불가함을 알 수 있다. 이로써 Fig. 1(b)와 같은 구조물에는 Type B, C, D와 같이 구형 발전단구만이 설치될 수 있다는 것을 알 수 있고 이는 국내 80 년 주기에서 일최대순간풍속이었던 $60 \mathrm{~m} / \mathrm{s}$ 를 가정하였기 때문에 일반적인 상황에서는 매우 안정적인 것 또한 확인이 가능하다.
식 (2)에 나타났듯이 최대 인장 응력이 풍속의 제곱에 비례함을 이용한다면 $30 \mathrm{~m} / \mathrm{s}$ 풍속을 가정하여도 Type A는 설치가 불가능 하다는 것을 알 수 있다.

Fig. 4는 구형 발전단구들이 보에 부착되어 있을 때 기둥까지 포함한 구조물 전체를 나타낸 것이다. 발전단구에 가해지는 풍 하중으로 인해 기둥에 작용하는 최대 인장 응력과 최대 전단 응력은 각각 식 (3), 식 (4)로 구할 수 있다(Beer et al., 2009).

$$
\begin{aligned}
& \sigma=\frac{M c}{I}=\frac{3(2 N-1) F(H+H / 2)}{a b^{2}} \\
& \tau=\frac{T}{c_{1} a b^{2}}=\frac{2(N+1)^{2} F L}{8 c_{1} a b^{2}}
\end{aligned}
$$

이 때 단면의 가로, 세로 길이 $150 \mathrm{~mm}$ 로 설정하여 $c_{1}=0.208$ $(a / b=1.0)$ 이 되고 기둥의 높이 $H$ 는 $1 \mathrm{~m}$ 로 정한다. 결과는 Table 3 과 같으며 Type $\mathrm{B}, \mathrm{C}, \mathrm{D}$ 의 경우 모두 허용 인장 응력, 허용 전 단 응력에 비해 훨씬 작은 값을 가지므로 기존의 Fig. 1(a)와 같 은 구조물에 비해 훨씬 간단하며 가벼운 해당 구조물로도 안전 성을 확보할 수 있음을 알 수 있다.

본 연구에서 제안하는 태양광 발전 시스템은 해양플랜트에 추가적으로 설치되는 것이기 때문에 이 시스템이 실제 적용되 었을 때 해양구조물로써 해양플랜트 전체의 구조안전성을 평가 하는 것은 본 연구의 범위를 벗어나므로 고려하지 않았다.

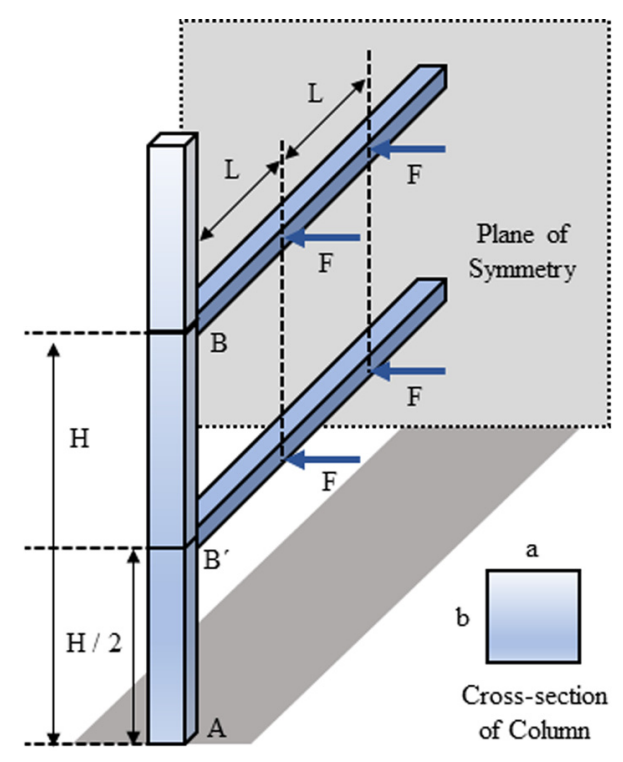

Fig. 4 Structure design for spheric panels

Table 3 Stress on the column

\begin{tabular}{ccc}
\hline \hline & Tensile stress, $\sigma$ & Shear stress, $\tau$ \\
\hline Type B & $6.56 \mathrm{MPa}$ & $15.58 \mathrm{MPa}$ \\
Type C & $5.59 \mathrm{MPa}$ & $13.26 \mathrm{MPa}$ \\
Type D & $4.53 \mathrm{MPa}$ & $10.74 \mathrm{MPa}$ \\
Allowable Stress, & $250 \mathrm{MPa}$ & $145 \mathrm{MPa}$ \\
(ASTM A36) & &
\end{tabular}




\section{5. 태양광 발전단구의 전력 실험}

본 장에서는 Table 1 과 같이 설계된 각 패널 별로 전력을 실 제 시제품을 이용하여 실험으로 구한 결과를 소개한다.

\section{1 전력 실험 조건}

본 연구에서의 전력 실험은 악조건에서의 전력을 산정하기 위하여 동절기 동안 각 패널의 성능을 평가할 수 있는 3 일간씩

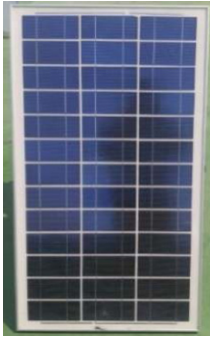

(A) Type A

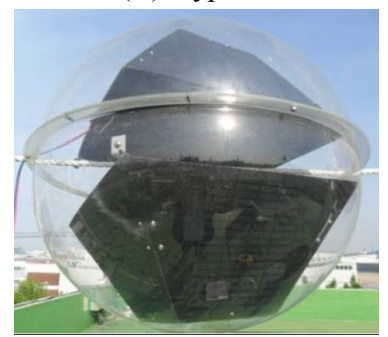

(C) Type $\mathrm{C}$

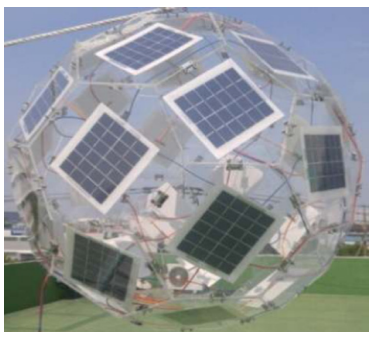

(B) Type B

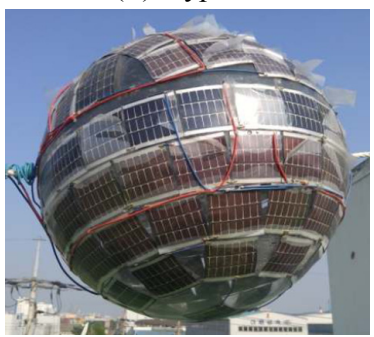

(D) Type D

Fig. 5 Photovoltaic panels used in test

을 선택하여 실행하였다(Type A와 B, Type A와 C, Type A와 D 를 각각 비교, 순서에 따라 Type A의 성능은 Type A1, A2, A3 로 표현하였다). 따라서 일반적인 경우, 본 실험을 통해 나온 결 과보다 더 좋은 성능이 나올 것으로 기대할 수 있다.

Fig. 5는 실제 전력 실험 시 각 형상 별 패널을 찍은 사진으로 Table 1의 내용과 더불어 본 연구에서 설계한 발전단구의 형태 를 파악할 수 있다.

전력 측정은 각 패널의 연결부하측에 $10 \Omega$ 의 저항을 연결하여 충전되는 전력을 확인하는 방식을 채택하였다. Table 4는 본 실 험이 진행된 기간의 대표적 기후상태를 도식화하여 나타낸 것이 다(총 18 일 $=$ 형상 비교군 3 개 $\times$ 비교군 별 3 일 $\times 2$ 회 반복 $).$

\section{2 전력 실험 결과}

Fig. 6는 전력 실험에서 얻어낸 전력, 전압, 전류를 시간대 별로 그래프로 나타낸 것이고 Table 5는 전력 결과만을 나타낸 표이다. 먼저 시간대별 결과를 보면 일조량이 가장 큰 오후 12시 1시를 전후로 모든 패널들의 최대 전력이 나오지만 시간대 별 전력의 차이는 Type A가 가장 큰 것을 알 수 있다. 이는 발전 패널 내 모든 셀들이 같은 방향을 향하고 있는 고정식 평판 방식의 특징을 잘 나타내는 것으로 이해할 수 있다. 이에 반해 Type $\mathrm{B}, \mathrm{C}, \mathrm{D}$ 는 셀들이 다양한 방향을 향하는 구조 덕분에 대체적으로 일조 방향 에 크게 상관없이 비슷한 양의 전력을 생산하는 것을 알 수 있다. 모든 경우에 적은 개수의 셀만 발전을 하기 때문에 일조량에 크게 영향을 받지 않는 것이다. 자세히 보면 Type B, C, D에서 형상이 둥글수록 편차가 더 작은 것을 확인할 수 있는데 이는 Type A의 편차가 큰 이유와 동일한 이유로 설명 될 수 있다.

Table 4 Weather conditions during the performance test

\begin{tabular}{|c|c|c|c|c|c|c|c|c|c|}
\hline & \multicolumn{9}{|c|}{ Date } \\
\hline \multicolumn{10}{|l|}{ Jan. } \\
\hline \multirow{3}{*}{$\begin{array}{c}16 \text { th } \\
\sim 24 \text { th }\end{array}$} & 16 & 17 & 18 & 19 & 20 & 21 & 22 & 23 & 24 \\
\hline & 0 & 3 & +0 & 3 & -2 & +4 & 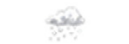 & 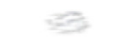 & $\geqslant$ \\
\hline & $-111^{\circ} \mathrm{C} \quad 3^{\circ} \mathrm{C}$ & $-9^{\circ} \mathrm{C} \quad 4{ }^{\circ} \mathrm{C}$ & $-5^{\circ} \mathrm{C} \quad 4^{\circ} \mathrm{C}$ & $-7^{\circ} \mathrm{C} \quad 5^{\circ} \mathrm{C}$ & $-7^{\circ} \mathrm{C}-1{ }^{\circ} \mathrm{C}$ & $-11{ }^{\circ} \mathrm{C}-1{ }^{\circ} \mathrm{C}$ & $-10^{\circ} \mathrm{C}-2{ }^{\circ} \mathrm{C}$ & $-12{ }^{\circ} \mathrm{C}-3{ }^{\circ} \mathrm{C}$ & $-14^{\circ} \mathrm{C} \quad 0^{\circ} \mathrm{C}$ \\
\hline \multicolumn{10}{|l|}{ Feb. } \\
\hline \multirow{3}{*}{$\begin{array}{c}\text { 7th } \\
\sim 15 \text { th }\end{array}$} & 7 & 8 & 9 & 10 & 11 & 12 & 13 & 14 & 15 \\
\hline & $\infty$ & 3 & 2 & 2 & 0 & 0 & 2 & $\geqslant$ & $\geq 9$ \\
\hline & $-6^{\circ} \mathrm{C} \quad 3^{\circ} \mathrm{C}$ & $-6{ }^{\circ} \mathrm{C} \quad 3^{\circ} \mathrm{C}$ & $-6^{\circ} \mathrm{C}-1{ }^{\circ} \mathrm{C}$ & $-8{ }^{\circ} \mathrm{C}-2{ }^{\circ} \mathrm{C}$ & $-8{ }^{\circ} \mathrm{C} \quad 0^{\circ} \mathrm{C}$ & $-9^{\circ} \mathrm{C} \quad 4^{\circ} \mathrm{C}$ & $-7^{\circ} \mathrm{C} \quad 5^{\circ} \mathrm{C}$ & $-4^{\circ} \mathrm{C} \quad 7{ }^{\circ} \mathrm{C}$ & $-6{ }^{\circ} \mathrm{C} \quad 9^{\circ} \mathrm{C}$ \\
\hline
\end{tabular}

Table 5 Comparison of power (in W) value according to time and panel

\begin{tabular}{|c|c|c|c|c|c|c|c|}
\hline Time $\quad$ Type & Type A1 & Type A2 & Type A3 & P (Avg.) & Type B & Type C & Type D \\
\hline 8:00 & 1.11 & 1.79 & 1.09 & 1.33 & 2.79 & 2.62 & 0.76 \\
\hline 9:00 & 5.6 & 5.39 & 5.42 & 5.47 & 4.18 & 3.28 & 1.13 \\
\hline 10:00 & 15.48 & 17.7 & 16.8 & 16.66 & 4.1 & 4.89 & 1.69 \\
\hline 11:00 & 25.29 & 27.48 & 26.39 & 26.39 & 3.07 & 5.94 & 1.73 \\
\hline $12: 00$ & 29.38 & 31.98 & 29.66 & 30.34 & 4.65 & 6.38 & 1.7 \\
\hline 13:00 & 30.69 & 27.59 & 31.37 & 29.88 & 5.7 & 5.73 & 1.77 \\
\hline 14:00 & 26.65 & 19.04 & 30.47 & 25.39 & 4.6 & 4.44 & 1.83 \\
\hline $15: 00$ & 5.07 & 16.59 & 12.48 & 11.38 & 4.17 & 5.44 & 1.77 \\
\hline $16: 00$ & 2.23 & 3.72 & 2.36 & 2.77 & 3.39 & 3.91 & 1.65 \\
\hline $17: 00$ & 2.76 & 5.1 & 2.14 & 3.33 & 2.58 & 3.39 & 1.35 \\
\hline 18:00 & 0.51 & 1.03 & 0.43 & 0.66 & 1.36 & 1.1 & 0.74 \\
\hline
\end{tabular}




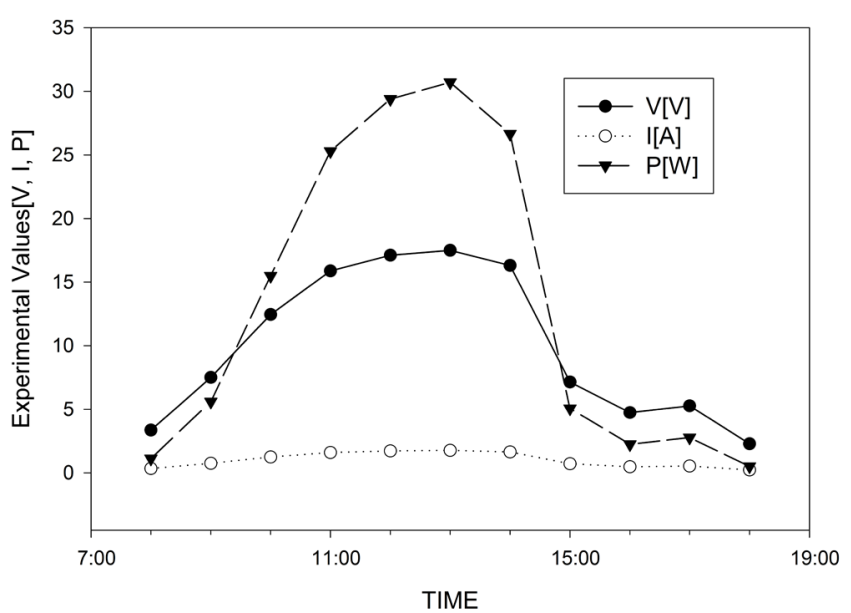

(a) Type A

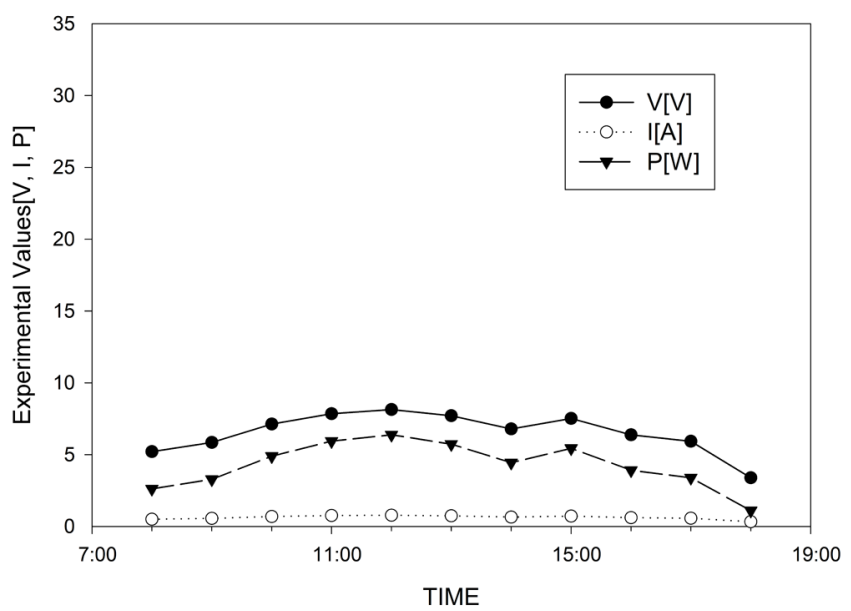

(c) Type $\mathrm{C}$

Fig. 6 Test result: Generated power of four types of panels

4장에서 이미 태양광 발전 패널을 보에 설치하는 구조의 발전 시스템에서는 Type B, C, D만 설치가 가능한 것으로 나왔기 때문 에 이 세가지 발전단구에 대해서만 결과를 보면 다음과 같다. Type B의 경우 Table 1에서 확인할 수 있듯이 나머지 두 종류의 패널에 비해 가장 높은 전력을 생산할 수 있지만 보다 더 평면 면적이 넓은 Type $\mathrm{C}$ 에 비해 발생 전력이 작은 것을 알 수 있었다. Type $\mathrm{D}$ 의 경우 원래 최대 발생 전력도 작은데다가 형상도 가장 둥글어 가장 작은 전력을 발생시키는 것으로 나타났다. 외부 구 형 막으로 인해 차단율이 일부 발생할 수 있다. 이를 통해 본 연 구에서 고려한 형상 별 패널 중에서는 Type B와 C가 Fig. 1(b)와 같은 구조물에 설치하기 적합하다고 판단할 수 있다.

\section{6. 제안 시스템의 경제성 분석}

동해-1 가스전의 경우 전체 $3,000 \mathrm{kWh}$ 의 전력량이 필요하며 현 재 평상시에는 가스 터빈을 이용하여 해당 전력량을 감당하고 있 고 비상전력공급은 전체 전력량의 $10 \%$ 규모인 $300 \mathrm{kWh}$ 을 생산할 수 있는 디젤 발전기를 이용하고 있다. 이러한 디젤 발전기를 대 체하여 본 연구에서 제안하는 시스템을 적용한다면 비상용 전력 량의 5 배 규모인 $1,500 \mathrm{kWh}$ 의 전력량을 저장할 수 있는 에너지 저

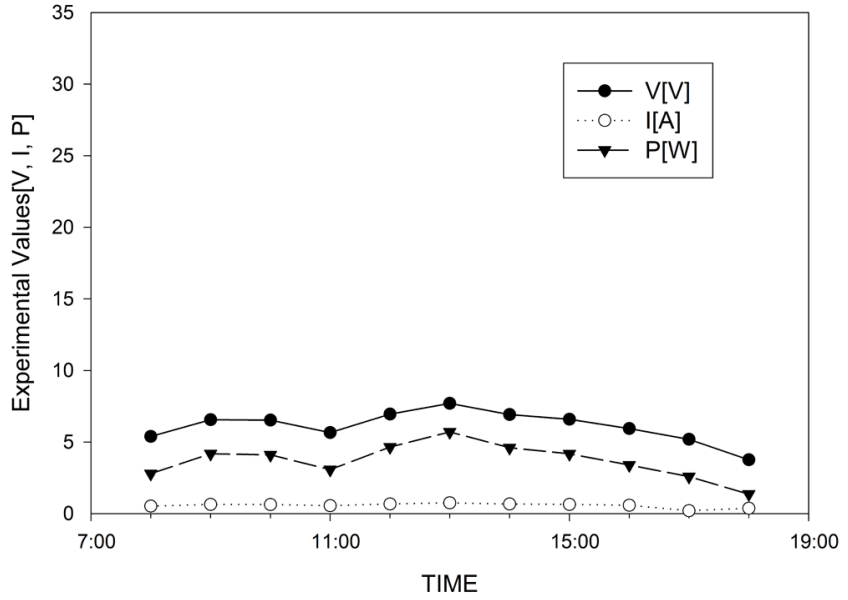

(b) Type B

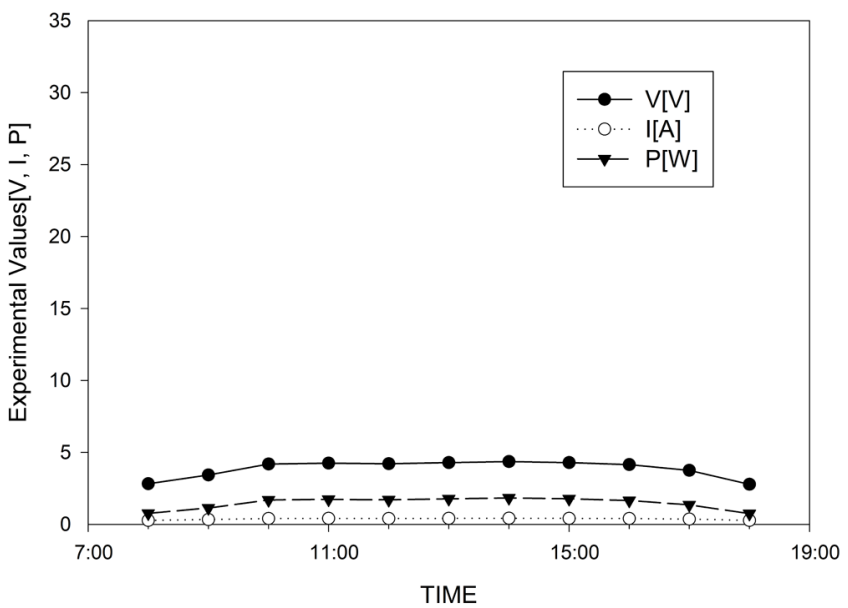

(d) Type D

장 시스템(ESS)을 설치하고 이를 충전하는 태양광 발전 시스템 은 $3 \mathrm{kWh}$ 용량으로 설계하는 것이 적정하다. 이는 5 장에서 이루 어진 실험 조건과 같이 하루 10 시간 충전을 기준으로 했을 때, 비 상시 $300 \mathrm{kWh}$ 의 전력량이 소모된다면 10 일 동안 충전하도록, $1,500 \mathrm{kWh}$ 의 전력량이 모두 소모된다면 50 일 동안 충전하도록 설 계한 것이다. 본 장에서는 해양플랜트에 Type $\mathrm{A}$ 를 설치한 시스템 과 Type $\mathrm{C}$ 를 설치한 시스템의 비용을 비교하므로 두 시스템에 공통적으로 이용되는 $\mathrm{ESS}$ 에 대해서는 고려하지 않았다.

또한 동해-1 가스전에 Fig. 1(a)의 구조물(Type A용 구조물)을 설치할 경우 플랫폼 상부에는 공간이 부족하여 바다 위로 돌출 된 형태로 설치되어야하지만 Fig. 1(b)의 구조물(Type B용 구조 물)은 플랫폼 상부에 바로 설치할 수 있다는 점이 본 장의 경제 성 분석에서 큰 비중을 차지한다.

Table 6는 태양광 발전시스템의 전력량이 $3 \mathrm{kWh}$ 가 되도록 Fig. 1(a)의 구조물에 Type A를 설치했을 때와 Fig. 4의 구조물에 Type $\mathrm{C}$ 를 설치했을 때의 CAPEX(Capital expenditure)를 나타낸 것이다. 5 장에서의 전력 실험 결과를 통해 Type A 패널은 약 200개, Type $\mathrm{C}$ 패널은 약 630개가 필요하다는 것을 알 수 있다. Type $\mathrm{A}$ 의 경 우 40개의 패널을 부착할 수 있는 구조물의 중량은 산업현장에서 평균 3.5ton, 동해-1 가스전에서와 같이 바다 쪽으로 돌출된 구조 
Table 6 CAPEX analysis result of solar cell installation in terms of panel types

\begin{tabular}{|c|c|c|c|}
\hline & & Items & Cost $(10,000 \mathrm{KRW})$ \\
\hline \multirow{5}{*}{$\begin{array}{c}3 \mathrm{kWh} \\
\text { Installation } \\
\text { cost }\end{array}$} & \multirow{2}{*}{$\begin{array}{c}\text { Planarity } \\
\text { (a) }\end{array}$} & Solar cell: 200 ea $\times 150,000 \mathrm{KRW} / \mathrm{ea}$ & 3,000 \\
\hline & & Structure: $(6.5+3.5)$ ton $\times(200 / 40) \times 12,500,000 \mathrm{KRW} /$ ton & 62,500 \\
\hline & \multirow[b]{2}{*}{$\begin{array}{l}\text { Sphericity } \\
\text { (b) }\end{array}$} & Solar cell: 630 ea $\times 150,000 \mathrm{KRW} / \mathrm{ea}$ & 9,450 \\
\hline & & $\begin{array}{l}\text { Beam: } 7.86 \text { ton } / \mathrm{m}^{3} \times 0.05 \mathrm{~m} \times 0.05 \mathrm{~m} \times 1.6 \mathrm{~m} \times 35 \times 500,000 \mathrm{KRW} / \text { ton } \\
\text { Column: } 7.86 \mathrm{ton} / \mathrm{m}^{3} \times 0.15 \mathrm{~m} \times 0.15 \mathrm{~m} \times 2 \mathrm{~m} \times 35 \times 500,000 \mathrm{KRW} / \mathrm{ton}\end{array}$ & 674 \\
\hline & & Profit on spherical panel (a)-b) & 55,376 \\
\hline
\end{tabular}

Table 7 OPEX analysis result of solar cell installation in terms of panel types

\begin{tabular}{|c|c|c|c|}
\hline & & Items & Cost $(10,000 \mathrm{KRW})$ \\
\hline \multirow{7}{*}{$\begin{array}{c}\text { OPEX per } \\
6 \text { years } \\
(313 \text { weeks })\end{array}$} & \multirow{3}{*}{$\begin{array}{l}\text { Planarity } \\
\text { (a) }\end{array}$} & Cleaning: $100,000 \mathrm{KRW} /$ person $\times 2$ people/time $\times 1$ time/week $\times 313$ weeks & 6,260 \\
\hline & & Replacing (panels): 200 ea $\times 150,000 \mathrm{KRW} / \mathrm{ea} \times 1$ time $/ 3$ years $\times 6$ years & 6,000 \\
\hline & & Replacing (labor): $1,500,000 \mathrm{KRW} /$ person $\times 4$ people $\times 2$ times & 1,200 \\
\hline & \multirow{3}{*}{$\begin{array}{l}\text { Sphericity } \\
\text { (b) }\end{array}$} & Cleaning: $100,000 \mathrm{KRW} /$ person $\times 1$ person/time $\times 1$ time $/$ week $\times 313$ weeks & 3,130 \\
\hline & & Replacing (panels): 630 ea $\times 150,000 \mathrm{KRW} / \mathrm{ea} \times 1$ time $/ 6$ years $\times 6$ years & 9,450 \\
\hline & & Replacing (labor): $100,000 \mathrm{KRW} /$ person $\times 6$ people $\times 1$ time & 60 \\
\hline & & Profit on spherical panel (a)-(b) & 820 \\
\hline
\end{tabular}

물이 필요한 경우 해당 구조물의 안전성을 위해 필요한 구조물의 중량이 평균 6.5 ton으로 구조물과 패널 가격의 총합은 약 6 억 6 천 만원인 것으로 나타났다. Type C의 경우 18 개의 패널을 부착할 수 있는 구조물이 총 35 개가 필요하며 ASTM A36의 밀도 $7.86 \mathrm{ton} / \mathrm{m}^{3}$ (Beer et al., 2009)을 이용하여 구조물의 가격만 매겼을 때는 약 674 만원 정도가 나오며 설치비용 전체는 약 1 억원으로 산정되었다. 즉, 본 연구에서 제안한 구형 태양광 발전시스템을 설치했을 경우는 구조물의 경량화와 단순화 덕분에 기존 시스템 에 비해 시설비가 5억5천만원 가량 경제적이란 뜻이 된다. 이는 구형 발전단구가 발전 효율은 낮아 많은 셀을 필요로 하지만 구 조물의 가격을 획기적으로 낮춰주기 때문이다.

Table 7은 위와 같은 조건일 때 각 시스템의 6년 당 OPEX (Operating expenditure)를 나타낸 것이다. 두 시스템 모두 일주일 에 1 회씩 청소 작업이 필요하지만 Type $\mathrm{A}$ 의 경우 돌출된 형태 의 발전 시스템을 청소하기 위해서는 안전을 위해 적어도 2 명 이상의 작업인원이 필요하기 때문에 청소를 위한 인건비가 2 배 이상 지출된다. 또한 Type A 패널에 비해 Type C 패널은 발생 하는 전력효율이 $1 / 3$ 수준이면서 구조물 자체가 간단하여 Type $\mathrm{A}$ 의 구조물에 비해 평소 청소를 통해 적상된 염분을 더욱 깨끗 이 제거할 수 있으므로 패널의 수명이 2 배 정도로 예상된다. 패 널의 교체 작업 시에 필요한 인력으로는 Type $\mathrm{A}$ 의 경우 해상, 고소에서 작업을 할 수 있는 전문인력이 필요하지만 Type $\mathrm{C}$ 의 경우 플랫폼 상부에서 바로 교체할 수 있기 때문에 이 부분에 서 인건비를 절감할 수 있다. 이렇게 계산된 OPEX에서 Type C 는 Type A에 비해 6년 당 820만원 저렴한 것으로 나타났다.

\section{7. 결 론}

해양플랜트 설비의 비상전원공급을 위한 태양광 발전시스템 은 일반적인 태양광 발전시스템에 비해 설계 시 풍하중의 영향
을 더 중요하게 고려해야한다. 기존 고정식 평판 태양광 발전시 스템은 풍하중을 줄이기 위한 설계가 아니라 풍하중을 견디는 설계 하에 완성되어 구조물의 하중이 크고 결국엔 계속된 풍하 중에 안전성이 떨어지게 되어 유지보수 비용이 많이 들었다.

본 논문에서는 이런 문제를 해결하기 위해 보에 태양광 발전 패널을 설치하는 방식의 태양광 발전시스템을 제안하고 보에 설치할 수 있는 구형 태양광 발전단구를 제시하였다. 이와 같은 방식은 기존 방식의 문제점을 해결할 뿐만 아니라 개별 패널의 고장 시 교체가 쉬운 장점까지 가지고 있다.

풍하중에 의한 응력을 분석함으로써 기존 평판식 발전 패널 과는 달리 구형 태양광 발전단구는 제안된 형식의 구조물(Fig. 1(b))에 설치할 수 있음을 보였고 시스템 측면에서 모듈 별 발 전량이 떨어지기 때문에 필요 전력을 채우기 위해 더 많은 패 널이 필요하지만 매우 저렴한 구조물 덕분에 경제성이 매우 높 다는 경제성 분석을 통해 제안 방식의 우수성을 입증하였다.

$$
\text { 후 기 }
$$

이 논문은 4차 산업혁명의 핵심으로 지목되는 친환경 에너지의 생산 비율을 높이는 방안과 $\mathrm{CO}_{2}$ 저감에 대한 에너지 생산 및 탄소 배출권 저감 모델을 제시한 것입니다. 이는 해양플랜트설비 친환 경 에너지 사업적 모델을 제시한 연구, 실험의 근거로 작성 되었으 며, 해양대기 환경개선을 위해 $\mathrm{CO}_{2}$ 를 저감하는 친환경 에너지의 비율 증가에 기여하고자 합니다. 한국해양과학기술원, 극지연구 소, 실험에 협조해주신 관계기관·기업에 감사드립니다.

\section{References}

Abdullah, M., Ahmed, M., Hasan, K., 2018. Feasibility Study on Hybrid Renewable Energy to Supply Unmanned Offshore 
Platform. Sustainable Electrical Power Resources through Energy Optimization and Future Engineering, 65-85.

Beer, F., Johnston, E., DeWolf, J., Mazurek, D., 2009. Mechanics of Materials. $5^{\text {th }}$ Edition, McGraw-Hill Education (Asia), Singapore.

Choi, H., Byun, I., Lee, N., Lee, S., 2010. The Study on Floated Photovoltaic Solar Energy Application to Dam Reservoir. Proceedings of The Korean Institute of Electrical Engineers Symposium, 1267-1268.

Fox, R., Pritchard, P., McDonald, A., 2010. Introduction to Fluid Mechanics. $7^{\text {th }}$ Edition, John Wiley \& Sons Asia Pte Ltd, Singapore.

Ha, S., Lee, B., Ha, Y., 2012. Analysis of Wind Pressure Distribution on Solar Collector in according to the Array of Module and the Angle. Proceedings of WEIIK Symposium, 127-132.

Jeon, J., Kim, K., 2010, An Optimal Decision Model for Capacity and Inclining Angle of Residential Photovoltaic Systems. The Transactions of the Korean Institute of Electrical Engineers, 59(6), 1046-1052.

Kang, M., 2016, Installation and Maintenance of Photovoltaic Facilities for Apartment. Journal of Electrical World Monthly Magazine, 470, 55-63.

Kim, J., Jeong, S., Kim, B., Ha, Y., 2013. Characteristics of Wind Pressure Distribution According to the Height of Support of Photovoltaic System. Proceedings of WEIIK Symposium, 61-66.

Kim, Y., Jeong, K., Lee, J., 2017. Wind Load Analysis for Designing a Tracking Solar Generator. Journal of the Korea AcademiaIndustrial Cooperation Society, 18(2), 672-680.
Lee, D., Jeong, S., Kim S., Kim, P., Yang, Y., 2017a. Analysis of Cost Effectiveness on Fishing Trip Cost by Adopting Photovoltaic Power Generation System in a Small Fishing Vessel. Journal of the Korean Society for Fisheries and Marine Sciences Education, 29(5), 1470-1479.

Lee, D., Kim, G., Tac, D., Yi, Y., Choi, J., Kim, H., Lee, J., Yoon, S., 2015. Diagnosis of Scoping and Type of Review on the Marine Environmental Impact Assessment for Ocean Energy Development Project. Journal of the Korean Society for Marine Environment and Energy, 18(3), 179-188.

Lee, I., Joo, J., Lee, C., Kim, G., Woo, D., Kim, J., 2017b. Evaluation of the Water Quality Changes in Agricultural Reservoir Covered with Floating Photovoltaic Solar-Tracking Systems. Journal of Korean Society of Environmental Engineers, 39(5), 255-264.

Oh, K., Moon, B., Lee, K., 2016. Performance Evaluation and Technical Development of Eco-environmental Photovoltaic Leisure Ship with Sail-controlling Device With Respect to Solar-Gybrid Generating System. Journal of Ocean Engineering and Technology, 30(1), 57-67.

Sahu, A., Yadav, N., Sudhakar, K., 2016. Floating Photovoltaic Power Plant: A Review. Renewable and Sustainable Energy Reviews, 66, 815-824.

Sanchez, Y., Oliveira, S., 2015. Exergy Analysis of Pffshore Primary Petroleum Processing Plant with CO2 Capture. Energy, 88, 46-56.

Shin, K., 2015. New Renewable Energy System Engineering. $1^{\text {st }}$ Edition, Iljinsa, Seoul. 